\title{
Interpersonal Meaning In Donald Trump's Speech In Response To Coronavirus Pandemic
}

\author{
Vivi Heryanti Damanik, T.Thyrhaya zein, Nurlela \\ Fakultas Ilmu Budaya Universitas Sumatera Utara \\ Email corresponding author: viviheryantidamanik@students.usu.ac.id
}

\begin{abstract}
This research is to examine the use of Mood and Speech Function in Donald Trump's speech in response coronavirus pandemic. The rise of the coronavirus pandemic that occurred in almost all parts of the world in December 2019 - 2020 which has not yet ended, made America the largest country affected by the coronavirus pandemic after Italy. This thing has made Donald Trump speaking out in an effort to stop the spread of the coronavirus in America. The analysis of this research based on Eggins (2004:14) which includes Realization of Speech Function in mood system. This paper concerns on the analysis of Mood and Speech Function in Donald Trump's speech in response coronavirus pandemic. This uses descriptive research method, in which the data are described systematically to get an accurate and factual result. The data used in this study are the clauses containing of grammatical mood and speech function used by Donald Trump's speech. The finding describes that as a president want to give his response to the spread of this global pandemic. Where the response is in the form of information and opinions carried out in preventing the spread of the coronavirus pandemic to the citizens of America. It also to analyze how the mood and speech function realized in Donald Trump's speech.
\end{abstract}

Keywords: Interpersonal Meaning, Mood System, Speech Function, Systemic Functional Linguistics

\section{INTRODUCTION}

The COVID-19 pandemic is a worldwide event of the spread of the coronavirus disease 2019, which is abbreviated as COVID-19. The COVID-19 outbreak was first detected in Wuhan City, Hubei Province, China in December 2019, and was declared a pandemic by the World Health Organization (WHO) on March 11, 2020. As of April 23, 2020, more than 2,000,000 cases of COVID-19 have been reported in more than 210 countries and territories.

America is one of the countries that have been heavily affected by the coronavirus with a fairly large death rate. The steps Donald Trump takes will determine the spread of the corona virus internationally. The pandemic has brought almost all economic activity in the US to a halt since around March, Trump imposed a stay-at-home order in an effort to stop the spread of the virus that causes the Covid-19 disease. The coronavirus pandemic has reached a tipping point. The steps taken over the next few days, especially by Donald Trump as President of America will determine the spread of the virus internationally.

Interpersonal meaning is a technical term in Systemic Functional Grammar (SFG) related to someone's attitude and judgments. In an utterance, there is meaning that wants to be delivered to the hearer. Halliday in Beaugrande (1991:245) explains briefly that the interpersonal metafunction concerns forms of interaction and embodies all use of language to express social and personal, how the interpersonal meaning is constructed in such situation. 
In this study, the researcher analyzed Donald Trump's speech in response to coronavirus pandemic, how his response to coronavirus disease which is almost spread all over the world, which is also known as the coronavirus or COVID19 which caused an outbreak of pneumonia in Wuhan city, China in 2019, and began to spread to many other countries. In communicating his notion about this issue, and In order to look deeper about Donald Trump's speech judgement through his statement, the researcher decides to use interpersonal meaning to analyze the speech. Interpersonal meaning is one of three metafunctions that Halliday states in his book. Interpersonal meaning itself is the way of the usage of language to communicative, express the feeling, understand the judgment with the audiences (Halliday,2004:11).

In Halliday's Systemic Functional Linguistics, interpersonal function is described as any function that makes people interact with each other through language. That is language is organized to express a certain interactive event that involves speaker/writers and listeners (Halliday, 2000). Here, the interpersonal meaning is used by Trump to interact as a speaker and the public as a listener. Through Donald Trump's interpersonal meaning, he expresses and identifies the ideas he conveyed in his speech in addressing the Corona Virus that is rife in the wider community. Donald Trump as the leader of the country also strengthens relationships with the community to influence people's behavior and attitudes in responding to this problem.

In Halliday's Systemic Functional Linguistics, interpersonal function is described as any function that makes people interact with each other through language. That is language is organized to express a certain interactive event that involves speaker/writers and listeners (Halliday, 2000). In fact, the language function served as interactive form between speakers and listeners is called interpersonal function. In this way language is used to establish and maintain appropriate relationship among people (Thompson, 2000). In addition to identifying speakers, interpersonal meanings also express attitudes, motivational speakers and so on. Through interpersonal functions, social groups are separated from each other, individuals can express and identify themselves, strengthen their relationships with others and efforts to influence the behavior and attitudes of others through mood and modality system.

The researcher discussed the interpersonal meaning of Donald Trump to his nation, which was conveyed from the oval office on March 11, 2020. Interpersonal meaning analysis deals with two components, namely speech function and mood structure. The function of speech is a person's way of conveying ideas communication to make the listener understand the idea well. When exchanging and expressing ideas, humans perform two roles, namely giving and demanding, for commodities such as information and goods or services. The speech function itself can divide into four types: statements, questions, orders, and offers. The writer analyzing interpersonal meaning in Donald Trump's speech by looking deeply at Mood Structure the clauses in the speech. Speech is divided into clauses, where each will be analyzed interpersonal.

Research on meaningful approaches interpersonal work has not been done by many other researchers. To see progress from previous studies that did discourse analysis with the SFL approach, researchers got some references. This matter It's important to get gaps or research gap that hasn't been researched and is able to developed. Other researchers like Fatonah and Mulatsih (2018), Amalia and Subandowo (2018), Firmansyah, A. (2015), Olusegun O. Jegede (2015). 
From the previous study above, it helps the researcher to develop the idea of how the mood structures are realized in the speech function of Donald Trump's speech. Based on the previous study, the researcher found that there is still no research which described in detail about the elements of the speech function type based on its function. Previous research mostly examined speech functions based on their type. Therefore, in this study, researcher explored the elements of the speech function based on their functions in each clause.

The main issues addressed in this study are the interpersonal meaning of Donald Trump found in his speeches. The inquiry towards these issues is formulated in the following research questions:

1. What types of Mood are used in Donald Trump's speech in response to the coronavirus pandemic?

2. How are speech functions realized in mood system in Donald Trump's speech in response to the coronavirus pandemic?

\section{LITERATURE REVIEW}

Other research has provided in many journals. There are similar previous researches that related to researchers' research topic. Therefore, the research uses these researches as the developing of ideas. Four similar previous researches below are: Some of the research has analyzed mood and speech functions. The first is an International Journal of English Lingustics by Olusegun O. Jegede (2015). This journal entitles Analyzing Interpersonal Metafunction through Mood and Modality in Muhammadu Buhari's Acceptance Speech.The findings revealed that declarative clauses were used more frequently than imperative and interrogative clauses because an acceptance speech gives the speaker the opportunity to give his listeners as much information as possible. The findings also revealed that the modal verb 'will' was more frequently used than others such as 'can', 'must' and should because the speech is an opportunity for the speaker to reveal his future plans for the addressees.

The second research is Fatonah and Mulatsih (2018) described the kinds of speech function and interpersonal role created by all speakers in Allison L. Randall's short story "End of The Line". This research used the theory of interpersonal metafunction by Halliday. This study contributes the researcher to develop the idea of interpersonal metafunction by using Halliday's theory.

The third research is a journal by Amalia and Subandowo (2018) examines the moods and modality types in interpersonal meaning of SBY's speech under the title "Toward Harmony among Civilizations" by Dr. Susilo Bambang Yudhoyono. This research used the theory of interpersonal metafunction by Halliday. He found there were two mood types in interpersonal meaning of SBY's speech namely indicative and imperative type, and the dominant mood in SBY's speech was the indicative type.

The fourth research is Firmansyah, A. (2015) investigates how the interpersonal meaning is realized in the speech of Israeli Prime Minister Benjamin Netanyahu. It applies Halliday theory of Systemic Functional Grammar (SFG) in analyzing the research data. Two different transcribed speeches are discovered to extract the data which are needed to investigate the interpersonal meaning. Subject, Finite and Modality are the main tools to realize the interpersonal meaning of Netanyahu in his speech. It can be realized by discovering the use of those parts in his speech in different issue and occasion. He found that 
Netanyahu's interpersonal meaning is realized through the placement of Subject and the utilization of Finite, Modality and Mood Adjuncts.

This research is hoped to complete the research and the journal before. This analyzed not only types Mood and Speech Function but also realization the speech function in mood system in Donald Trump's Speech.

\section{RESEARCH METHOD}

The research method in this study covers research design, unit of analysis, source of data, method of data collection and method of data analysis. The researcher uses descriptive research method, in which the data were described systematically to get an accurate and factual result. The data analysis in the research uses qualitative analysis, Qualitative research is a procedure of research which produces descriptive data in the form of written words or oral words about the object that is observed. This method is used to analyze and to describe the mood and speech functions uses in Donald Trump's speech.

The data used in this study consist of the clauses such as grammatical mood and speech function used by Donald Trump in his speech. The data of this research are written. The data consist of the script of Donald Trump's speech taken from https://edition.cnn.com/2020/03/11/politics/read-trump coronavirusaddress/index.html. The data were chosen because Donald Trump is one of the best president in the world and also information is very important for the American people to stop the coronavirus pandemic.

Data collection is a systematic procedure and standardization to obtain the necessary data (Miles and et al, 2014:1). Data collection techniques used in this study are see and note taking techniques. Seeing technique used to scrutinize to the language used. The term of scrutinizing here is no $t$ only related to the use of language orally, but also the use of language in writing (Mahsun: 2005). The seeing technique in this research uses the advanced techniques in the form of note taking technique. Note taking technique is to note several forms that are relevant for this research from the use of language in writing (Mahsun: 2005). The technique will be done with these following steps:

1. Watching the video of Donald Trump's speech

2. Downloading the script of the Donald Trump's speech.

3. Reading and examining carefully the data.

4. Finding out and identifying all the clauses which containing the Interpersonal Meaning of data.

5. Identifying the grammatical Mood and Speech Function realization in the script.

6. Classifying grammatical Mood and Speech Function of clauses used by Donald Trump the script.

7. Tabulating the mood based on the types, realization and reason.

8. Analyzing the grammatical Mood and Speech Function realization in the script.

Data analysis techniques used in this study are Interactive Model Techniques by Miles \& Huberman. According to Miles \& Huberman (Miles:1994) in this model there are four components of analysis, namely data collection, data display, data condensation and conclusion drawing (verification). Data analysis will be done with the following steps:

1. Collect the data by reading, describing and identifying the texts from Donald Trump's speech based on Halliday's theory. 
2. Identifying each clause based on grammatical mood and speech function in Donald Trump's speech.

3. After being identified, the next step is to classifying them based on the kinds of grammatical mood and speech function used by Donald Trump in his speech on March 11th, 2020 with the topic about "Coronavirus Pandemic".

4. After determining the kinds of grammatical mood and speech function, it is made realization of speech function in mood system based on interpersonal function.

5. Classifying the use of typical clause mood and non typical clause mood in Donald Trump's speech.

6. Abstracting the data, the data was analyzed using Halliday's theory. The analysis theories were analysis of text from Donald Trump's speech.

7. Drawing conclusions and giving suggestions.

\section{RESULT AND DISCUSSION}

In this section, the researcher tries presents findings related to meaning interpersonal. Findings in this study summarized in table. Analyze mood types and realize the speech function into the mood system to answer the formulation of the problem is presented its realization on the text of Donald Trump's speech.

\section{Mood Types in Donald Trump's Speech about Coronavirus Pandemic}

This part discussed about the Mood in Donald Trump's speech based on Mood types categorization such as Declarative, Interrogative, Imperative, and Modulated Interrogative. This is following examples showed how Mood was conducted in each clause in Donald Trump's speech.

Declarative can be identified from the position the Subject that precedes finite. A Declarative clause function to give information and this is called Statement (in Speech Function Realization). Declarative clauses were the most dominant used in Donald Trump's speech. Trump was an interviewee in this speech. He was as an informant, giving information and sharing idea. As President, Donald Trump has become a source of information, because his speech provided information to the public in dealing with the spread of the coronavirus.

\begin{tabular}{|c|c|c|c|}
\hline We & have & $\begin{array}{l}\text { the best economy, the most advanced health care, and the most } \\
\text { talented doctors, scientists and rsearchers anywhere in the } \\
\text { world }\end{array}$ \\
\hline S & F & P & Compliment \\
\hline Mood & & Residue \\
\hline
\end{tabular}

\begin{tabular}{|l|l|l|}
\hline This & Is & $\begin{array}{l}\text { the most aggressive and comprehensive effort to confront a foreign virus } \\
\text { in modern history }\end{array}$ \\
\hline S & F & \multicolumn{2}{c|}{ Compliment } \\
\hline Mood & & Residue \\
\hline
\end{tabular}

The examples above were called Declarative because the Subject preceded the Finite. Subject and Finite as Mood and the rests were called by residue. Based on the characterization of Declarative clause, all examples were declarative clauses. 
Interrogative sentence is a sentence that asks about a question. The term is used in grammar to refer to features that form questions. Thus, an Interrogative sentence is a sentence whose grammatical form shows that it is a question. Such sentences may exhibit an Interrogative of grammatical Mood. This applies particularly to languages that use different inflected verb forms to make questions. However, interrogative is not much different from declarative, where the finite is placed in front and followed by the subject.

\begin{tabular}{|c|c|c|}
\hline Which & is & Unprecedented to provide financial relief. \\
\hline W-h Question & F & C \\
\hline \multicolumn{2}{|c|}{ M } & R \\
\hline
\end{tabular}

From the example above, Interrogative in Mood realized Question in Speech Function. It was concluded that Interrogative clause was started by W-h Question such as What and Why. There was no other Interrogative found such as yes/no questions.

Imperative clauses typically do not contain the element of subject or finite, but they consist of a predicator, plus any of the non-core participant of complement and adjuncts. Imperative clauses are the Mood typically used for exchanging goods and services. The Mood element of Imperative clause may consist of Subject + Finite, Subject Only, or the Imperative clauses may not have Mood element, but there will always be a Predicator.

\begin{tabular}{|c|c|c|}
\hline \multicolumn{2}{|c|}{ Wash } & your hands \\
\hline F & P & Compliment \\
\hline Mood & \multicolumn{2}{c|}{ Residue } \\
\hline \multicolumn{2}{|c|}{ Clean } & often-used surfaces \\
\hline F & P & Compliment \\
\hline Mood & \multicolumn{2}{c}{ Residue } \\
\hline
\end{tabular}

Predicator preceded Subject and Finite called Mood was an Imperative. The examples above were imperative if analyzed in Mood. Imperative in Mood was realized in Command in Speech Function.

Modulated Interrogative Clause is an offering. This clause is the least clause used in Trump's dialogue. Modulated Interrogative Clause is not Congruent in Speech Function, because the Modulated Interrogative clauses used were Statement in Speech function analysis.

\begin{tabular}{|c|c|c|}
\hline If & You & sneeze or cough, cover your face and mouth \\
\hline P & S & C \\
\hline M & & R \\
\hline
\end{tabular}

\begin{tabular}{|c|c|}
\hline It & Only matters how you respond \\
\hline S & $\mathrm{C}$ \\
\hline $\mathrm{M}$ & $\mathrm{R}$ \\
\hline
\end{tabular}

The findings of the categorization were then, quantified, and the overall findings were summarized in the table below. 
Mood Types in Donald Trump's speech

\begin{tabular}{|l|l|c|c|c|c|c|c|c|c|}
\hline \multicolumn{9}{|c|}{ Mood } & \multicolumn{2}{l|}{ Total } \\
\hline \multicolumn{2}{|l|}{ Declarative } & \multicolumn{2}{|c|}{ Interrogative } & \multicolumn{2}{l|}{ Imperative } & \multicolumn{2}{c|}{$\begin{array}{c}\text { Modulated } \\
\text { Interrogatives }\end{array}$} & \multicolumn{2}{l|}{} \\
\hline Freq & $\%$ & Freq & $\%$ & Freq & $\%$ & freq & $\%$ & Freq & $\%$ \\
\hline 82 & $81.18 \%$ & 1 & $0.99 \%$ & 15 & $14.85 \%$ & 3 & $3.03 \%$ & 99 & $100 \%$ \\
\hline
\end{tabular}

From the table 4.1.1 it can be seen that all Mood types were found in Donald Trump's speech, there are Declarative, Imperative, interrogative and Modulated Interrogatives. In the table above, there are $82(81.18 \%)$ declarative clauses in the data. It means that Declarative clauses are more than others. Interrogative clause there is $1(0.99 \%)$, Imperative clauses are $15(14.85 \%)$ clauses, and the least clause is Modulated Interrogative are 3 clause (3.03\%).

Declarative can be identified from the position the Subject that precedes finite. A Declarative clause function to give information and this is called Statement (in Speech Function Realization). Declarative clauses were the most dominant used in Donald Trump's speech. Trump was an interviewee in this speech. He was as an informant, giving information and sharing idea. As President, Donald Trump has become a source of information, because his speech provided information to the public in dealing with the spread of the corona virus.

Imperative clauses typically do not contain the element of subject or finite, but they consist of a predicator, plus any of the non-core participant of complement and adjuncts. Imperative clauses are the Mood typically used for exchanging goods and services. The Mood element of Imperative clause may consist of Subject + Finite, Subject Only, or the Imperative clauses may not have Mood element, but there will always be a Predicator.

Interrogative sentence is a sentence that asks about a question. The term is used in grammar to refer to features that form questions. Thus, an Interrogative sentence is a sentence whose grammatical form shows that it is a question. Such sentences may exhibit an Interrogative of grammatical Mood. This applies particularly to languages that use different inflected verb forms to make questions. However, interrogative is not much different from declarative, where the finite is placed in front and followed by the subject.

Modulated Interrogative Clause is an offering. This clause is the least clause used in Trump's dialogue. Modulated Interrogative Clause is not Congruent in Speech Function, because the Modulated Interrogative clauses used were Statement in Speech function analysis.

\section{Realization of Speech Function in Mood System in Donald Trump's Speech in response to corona virus pandemic}

There are two realizations of speech functions in mood system, namely typical clause mood and non-typical clause mood. In typical clause mood, statement was realized by declarative, command was realized by imperative, question was realized by interrogative, and offer was realized by modulated Interrogative.

In non- typical clause mood, question was realized by modulated declarative, but there is no found in Donald Trump's speech. Command was realized by declarative, and offer was realized by declarative. 


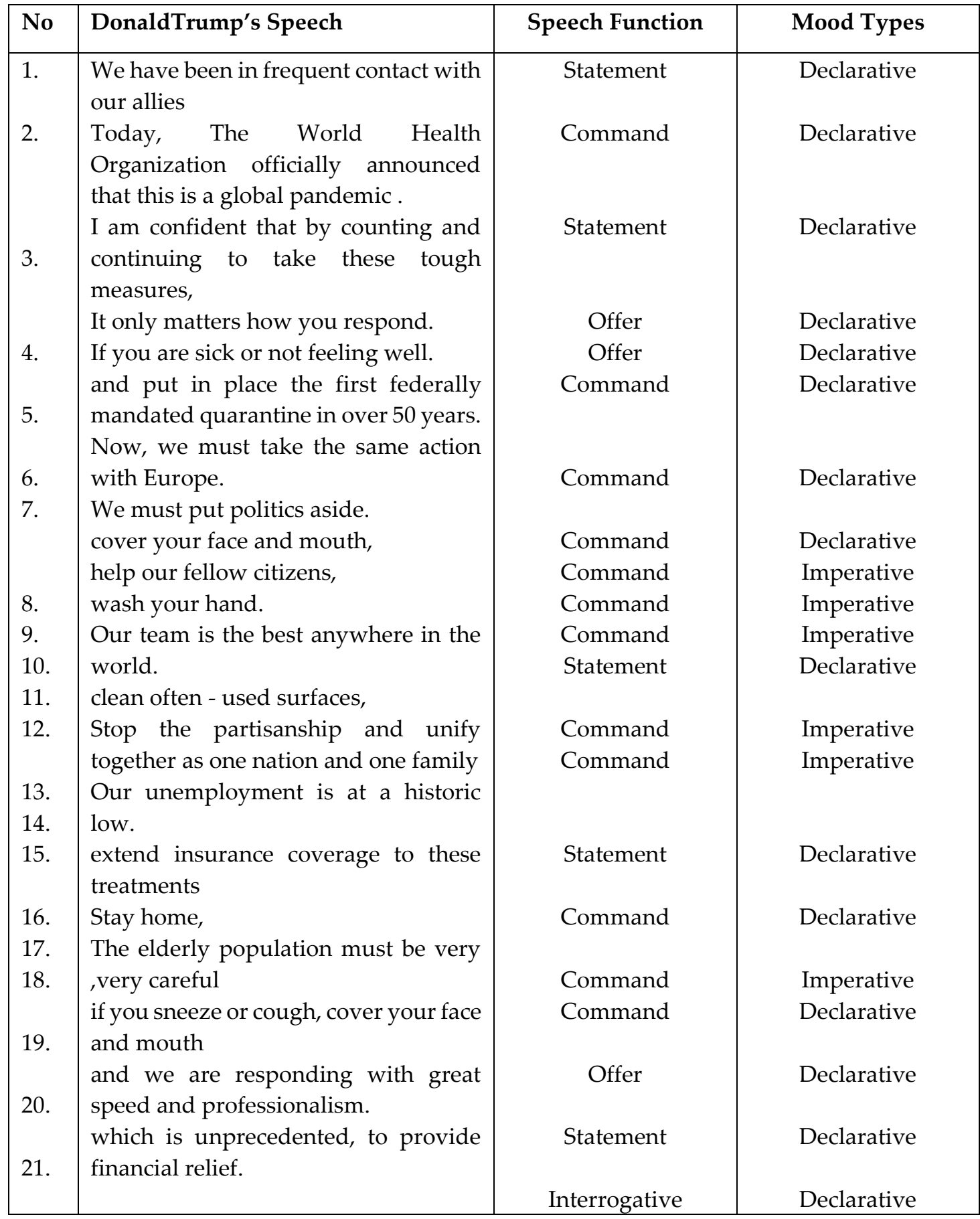

Based on the table above, it is found that Donald Trump's clauses are Command that realized in the declarative. Commands are usually coded by imperative clauses, but commands can also be coded by declarative. It showed non-typical clause mood. The clause structurelly like an ordinary declarative but functionally different. Offer that realized declarative. Offer are usually coded by modulated interrogative clauses, but offer can also be coded by declarative. It showed non-typical clause mood. In demonstrating this statement, he uses an Imperative clause. Questions are realized declarative. Question is usually coded by interrogative clause. 
But interrogative can also coded by declarative. It showed non-typical clause because the question clause is manifested in a declarative form.

The followings are the summaries of realization of speech function in mood system employed by Donald Trump during the observation.

\section{Realization of Speech Functions in Mood System}

\begin{tabular}{|c|c|c|c|c|c|}
\hline \multirow{2}{*}{$\begin{array}{c}\text { Speech } \\
\text { Function }\end{array}$} & Number & \multicolumn{4}{|c|}{ Mood System } \\
\cline { 3 - 6 } & $\begin{array}{c}\text { Typical Clause } \\
\text { Mood }\end{array}$ & Number & $\begin{array}{c}\text { Non -Typical } \\
\text { Clause Mood }\end{array}$ & Number \\
\hline Statement & $82(81.18 \%)$ & Declarative & $94(93,06 \%)$ & $\begin{array}{c}\text { Tagged } \\
\text { Declarative }\end{array}$ & - \\
\hline Command & $15(14.85 \%)$ & Imperative & $7(6.93 \%)$ & Declarative & $15(15.15 \%)$ \\
\hline Question & 1 & Interrogative & - & Declarative & $1(0.99 \%)$ \\
\hline Offer & $3(3.03 \%)$ & $\begin{array}{c}\text { Modulated } \\
\text { interrogatives }\end{array}$ & - & Declarative & $3(2.97 \%)$. \\
\hline
\end{tabular}

\section{DISCUSSION}

Speaking from the Oval Office, Mr Trump announced a 30-day suspension of travel from Europe, starting on Friday 11 March 2020. Donald Trump wants to talk to his people about the unprecedented corona virus outbreak, started in China and is now spreading around the world. Speeches are products of human minds reflecting ideas and opinions of the speakers. It can be seen in Donald Trump's speech. Donald Trump try to describe how Donald Trump's language style can influence society in the United State.

In this study it was found that Donald Trump was different in delivering his speech, as president, Donald Trump is very concerned about his people with great care in delivering his speeches. In determining types of mood occurred in the Donald Trump's speech According to Halliday (2004) there are four types of mood structure, namely declarative, imperative, interrogative, and modulated interrogative.

The use of the declarative mood to inform the citizen about Donald Trump values as what was stated previously was regarded as his efforts to convince other people that he was strong leader and he had qualities that made his fit into the position to be the leader of the country. Another purpose of employing the declarative mood in Donald Trump's speeches about coronavirus was to show Trump competence in stating visions and missions. By employing the declarative mood, Donald Trump told their public about where he was going to protect their country in overcoming the problem. By doing this, Donald Trump could show their public that they were a visionary leader. He wanted to show that they had the competencies to make their public believe that they deserved to be chosen. Another aim of using the declarative mood in the speeches was to show their.

Donald Trump was a President, he usually sold feeling and idea and he used this strategy in his speech in social media. Donald Trump gave questions with declarative or statement. In this research, Trump used his Command, Question and Offer clause realized in declarative. Interrogative clause realized in Statement, Imperative clause realized in 
Statement. This was non- typical clause mood. The most dominant was declarative clause realized in statement and it was prevalent.

\section{CONCLUSION}

The higher intellectual of each person is, the better the choice of clause is used. Donald Trump as the America President used typical mood and non typical mood in her clause. In conveying the speech, he must give the most interesting style in getting the audience's attraction. One of the ways is by using non typical clause mood in delivering her statement, question and command. He expresses and identifies the idea he conveyed in his state speech in addressing the coronavirus that is rife in the wider community. Donald Trumps as the leader of the country also strengthens relationships with the community to influence people's behavior and attitudes in responding to this problem. Interpesonal Meaning is one of the ways of the usage of language to communicative, express the feeling, understand, the judgment with the audiences. Furthermore, this research can be used to learn and to study meanings such as interpersonal meaning and grammatical mood and speech function. Hopefully, this research is able to solve the problem in learning interpersonal meanings and to add information for the readers which the best way in doing speech, dialogue or conversation.

\section{REFERENCES}

Amalia, M. Subandowo, D. (2018). An Analysis of Domain Mood and Modality of InterpersonalMeaning in SusiloBambangYudhoyono (SBY)'s Speech. English Language Teaching Educational Journal (ELTEJ). 1(1), 22-28

Butt, et.al. (1995). Using Functional Grammar: An Explorer's Guided.Sydney:MacquarieUniversity

Edward Sapir. (1921). An Introduction to the study of speech. New york: HARCOURT, BRACE, 1921.

Eggins, S. (2004).An Introduction to Systemic Functional Linguistics. London:Continuum

Ezeifeka, Chinwe R. (2014). Critical Discourse Analysis of Interpersonal Meaning of PowerRelations in Selected Inaugural Political Speeches in Nigeria. Unizik Journal of Arts andHumanities Vol.14. Retrieved from:

http://www.ajol.info/index.php/ujah/article/view/101194

Fatonah, E. Mulatsih, S. (2018). Speech Functions Used by Speakers in Allison L. Randall'sShort Story “End of the Line". E-Structural. 1(1), 39-57.

Firmansyah, A. (2015) investigates how the interpersonal meaning is realized in the speech of Israeli Prime Minister Benjamin Netanyahu. Journal Of English Education.

George Lakoff, 1992. To Appear in Ortony, Andrew (ed.) Metaphor and Thought (2nd edition), CambridgeUniversity Press.

Halliday,M.A.K.(1994). An Introduction to Functional Grammar.London:Oxford UniversityPress

Halliday, M.A.K. (2000) An Introduction to Functional Grammar. Foreign Language Teaching and Research Press, Beijing.

Halliday, M.A.K, Matthiesen. (2004). An Introduction to Functional Grammar.London:OxfordUniversity Press. 
Halliday, M. A. K. (2007). Language and Society. London: Continuum.

Martin, J. R. (1992). English Text: System and Structure.USA : John Benjamins PublishingCompany

Methapor (1992)." Metaphor Understanding and Accessing Conceptual Schema: Reply to Gibbs (1992)".Matthew S. McGlone Princeton University

Miles,M.B, Huberman,A.M, dan Saldana,J. 2014. Qualitative Data Analysis, A Methods Sourcebook, Edition 3. USA: Sage Publications. Terjemahan Tjetjep Rohindi Rohidi, UI-Press.

Olusegun O. Jegede (2015) Interpersonal Meaning in Nigeria's President Muhammadu Buhari's Victory Speech. Olusegun O. Jegede Department of English and Literary Studies Lead City University, Ibadan.

Otten, S.(2010). Discourse Analysis and Functional Grammar in the Classroom: the Summary ofa Mini-Reading Course. Retrieved from Michigan State University,https://www.msu.edu/ ottensam/954ottenMiniReading.pdf

Syairozi, M. I. (2017). Percepatan Pengurangan Kemiskinan Sektor Pertanian di Kabupaten Malang. In Seminar Nasional \& Call For Paper, FEB Unikama (pp. 145-155).

Thompson, 2000 - journals.sagepub.com. A Meta-Analysis of Responsen Rates in Web- or Internet-Based Surveys.

Ye, R.(2010). The interpersonal Metafunction Analysis of Barrack Obama's Victory Speech.English Language Teaching, Vol. 3, No. 2. Retrieved fromhttp://www.ccsenet.org/journal/index.php/elt/article/view/6258

Wijaya, K., \& Syairozi, M. I. (2020). Analisis perpindahan tenaga kerja informal Kabupaten Pasuruan. Jurnal Paradigma Ekonomika, 15(2), 173-182. 